\title{
Effects of pantoprazole as a HIF-1 $\alpha$ inhibitor on human gastric adenocarcinoma sgc-7901 cells
}

\author{
Y. SHEN, Y. WU, M. CHEN, W. SHEN, S. HUANG, L. ZHANG, X. ZOU* \\ Department of Gastroenterology, the Affiliated Drum Tower Hospital of Nanjing University, Medical School, No. 321, Zhongshan Road, Nanjing \\ Jiangsu 210008, P. R. China
}

*Correspondence: zouxiaoping795@hotmail.com

Received August 26, 2011 / Accepted September 22, 2011

\begin{abstract}
Previously, it has been demonstrated that HIF-1a has close connection with malignant tumor progression, aggressive behavior and prognosis. In addition, proton pump inhibitors (PPIs) have been reported to selectively induce tumor cell apoptosis, thus exerting its anticancer effects. In vitro and in vivo our study revealed that pantoprazole (PPZ) inhibited tumor cells proliferation, induced apoptosis and decreased the expression of HIF-1a protein. In summary, PPZ could suppress tumor growth acting as a HIF-1 $\alpha$ protein inhibitor.
\end{abstract}

Key words: gastric cancer, proton pump inhibitors, HIF-1 $\alpha$

HIF-1 is a heterodimer composed of two subunits, HIF- $1 \alpha$ and HIF- $1 \beta$, and they both have a structure of basichelix-loop-helix (bHLH)-PAS $[1,2]$. HIF- $1 \beta$ is constitutively expressed whereas HIF-1 $a$ varies following the oxygen density, which is degraded instantly in normal oxygen concentration conditions but is stable in hypoxic conditions $[3,4]$. Although malignant tumors tend to form many new vessels, because of severe structural and functional abnormalities of tumor microvessels, deterioration of diffusion geometry, decreasing oxygen transport capacity of the blood and increasing distances of diffusion from capillaries, some parts of tumor regions will be hypoxic $[5,6]$. It is suggested that HIF-1 $\alpha$ in tumor cells is stabilized as a result of the hypoxic environment developed in certain regions. In fact, HIF-1a has been revealed to be overexpressed in more than $70 \%$ of solid tumors [7].

Gastric cancer is the fourth most common cancer and the second leading cause of cancer related death in the world [8]. A lot of experiments have showed that HIF-1 $1 a$ is overexpressed in gastric cancer [9-12] and inhibition of HIF-1 $\alpha$ has proven

Abbreviations: BCA - bicinchoninine acid, bHLH - basic-helix-loophelix, CCK-8 - cell counting kit-8, DAPI - 4,6-diamidino-2-phenylindole, EDTA - ethylenediamine terraacetic acid, PBS - phosphate buffer saline, PMSF - phenymethylsulfonyl fluoride, PPIs - proton pump inhibitors, PPZ - pantoprazole, PVDF - polyvinylidene difluoride, SDS - sodium dodecyl sulphate, $\mathrm{SO}$ - sham-operated, TBST - tris buffer saline plus tween 20 anti-tumor effect $[13,14]$. The crucial role of HIF-1 $1 \propto$ in gastric cancer suggests that identifying the new inhibitors of HIF-1a should be a promising approach to the treatment of human gastric cancer.

Pantoprazole (PPZ), a type of proton pump inhibitors, acts as an inhibitor of $\mathrm{H}^{+}, \mathrm{K}^{+}$-ATPase of the gastric parietal cells. We hypothesized that the effect of PPZ on HIF-1 a may be related to its inhibitory efficacy on proton pump. Yeo et al. reported that PPZ selectively induced cancer cells apoptosis in vitro, and in a xenograft model of nude mice, the isolated tumor from mice with intratumoral administration of PPZ was remarkably smaller than that in the control group [15]. It is suggested that PPZ might provide an effective anticancer effects. However, little data have been focused on the involving mechanisms.

Our study have demonstrated that PPZ refrained proliferation and induced apoptosis selectively in SGC-7901 gastric adenocarcinoma cells, and significantly inhibited tumorigenesis in a tumor xenograft model. We also made an attempt to document the potential mechanism largely through the detection of HIF-1a protein. Our novel findings suggested that PPIs could be considered as a new important direction to anticancer therapy.

\section{Materials and methods}

Cell line, cell culture and experimental design. The human gastric adenocarcinoma cell line, SGC-7901, was kindly 
provided by Dr. Jing Sun from the Department of Oncology, the Affiliated Drum Tower Hospital of Nanjing University, Medical School. Cells were cultured in RPMI-1640 medium (Hyclone, USA) supplemented with $10 \%$ fetal bovine serum (Hangzhou Sijiqing Biological Engineering Materials, China) and antibiotics $(100 \mathrm{U} / \mathrm{ml}$ penicillin and $100 \mu \mathrm{g} / \mathrm{ml}$ streptomycin) in a humidified atmosphere with $5 \% \mathrm{CO}_{2}$ at $37^{\circ} \mathrm{C}$ (Thermo Direct Heat $\mathrm{CO}_{2}$, USA).

Pantoprazole sodium salts (Nycomed GmbH, Germany) were resuspended in normal saline $(0.85 \%)$ at $8 \mathrm{mg} / \mathrm{ml} \mathrm{im-}$ mediately before use. Cells were divided into 7 groups when cells fused to $60-70 \%$, in which PPZ was added with the final concentrations of $0,1,10,20,40,80$ and $160 \mu \mathrm{g} / \mathrm{ml}$ respectively, all cultured for $24 \mathrm{~h}$ and used for further experiments.

Animals and experimental design. All procedures and experiments that involved animals were approved by The National Animal Research Authority. Four-week-old female $\mathrm{BALB} / \mathrm{c}$ nude mice were obtained from Center of Comparative Medicine, Yangzhou University (Yangzhou, China). Animals were housed in an environment-controlled animal care facility with a constant room temperature and humidity. A 12-h light (started at 7:00 am), 12-h dark cycle was maintained throughout the whole experiment. All animals were fed laboratory chow and water ad libitum. Upon arrival, they were acclimated for at least 1 week and subsequently divided into three groups at random on the basis of body weight, including the sham-operated (SO) group, the control group and the PPZ treatment group.

The SGC-7901 cells were used to induce tumor formation in mice. In brief, on day 1 , tumor cells $\left(1 \times 10^{7}\right.$ cells in $0.2 \mathrm{ml}$ medium) were inoculated subcutaneously into the right subscapular flank of mice in the tumor-bearing animals (the control group and the PPZ treatment group). Mice in the SO group received injection with same amount of culture medium in identical places. General status and tumor size (length and width) were observed every other day. On day 9, mice in the PPZ treatment group were administered intragastrically with $75 \mathrm{mg} /(\mathrm{kg} \cdot \mathrm{d}$ ) PPZ for 10 days, and mice in the control group and the SO group were given equal volume normal saline in the same way. On day 18 , blanking $12 \mathrm{~h}$ after the last dose administration, all animals were killed, thereafter tumors were dissected, weighed and frozen at $-80^{\circ} \mathrm{C}$.

Western blotting analysis. Total cell extracts were prepared on ice for $30 \mathrm{~min}$ in lysate $(150 \mathrm{mM} \mathrm{NaCl}, 50 \mathrm{mM}$ Tris- $\mathrm{HCl}, \mathrm{pH} 8.0,0.1 \%$ SDS, $0.2 \%$ EDTA, $1 \%$ Triton X-100, $1 \%$ sodium deoxycholate, $0.01 \%$ PMSF) supplemented with protease inhibitors (aprotinin, leupeptin, phenylmethylsulfonyl fluoride, sodium orthovanadate; Roche), and centrifugated at $12000 \mathrm{rpm}$ in $4^{\circ} \mathrm{C}$ (Eppendorf centrifuge 5804R, Germany) for $15 \mathrm{~min}$ to remove nuclei and cell debris. In addition, tumor samples were subjected to homogenate ahead of total cell extracts. Protein concentration of the extracts was determined by the BCA Protein Assay Kit (KEYGEN Biotech, China), following the manufacturer's instructions. Fifty micrograms of each protein sample were subjected to Western blotting on a denaturating 10\% SDSpolyacrylamide gel electrophoresis and transferring to PVDF membranes (Immobilon-P, MILLIPORE, USA) using a semidry transfer system (Bio-Rad, USA). Non-specific binding was blocked by incubating the membranes in $1 \times$ TBST (Tris Buffered Saline containing 0.05\% Tween-20) supplemented with $5 \%$ nonfat dry milk for $1 \mathrm{~h}$. Blots were incubated with a monoclonal mouse antibody to HIF-1 $\alpha$ (1:1000, Chemicon, USA) and a monoclonal mouse antibody to $\beta$-actin (1:3000, Santa Cruz, USA) as an internal control for protein loading. Antibody binding was detected by incubating the blot with a horseradish peroxidase-conjugated goat anti-mouse antibody (1:1000, KPL, USA). Antibody staining was visualized by enhanced chemiluminescence (Santa Cruz, USA). The images of Western blot products were collected and analyzed by Quantity One V4.31 (Bio-Rad, USA).

Immunofluorescence staining analysis. Dispersed single cells $\left(2 \times 10^{5}\right.$ cells per well) were planted on $22 \times 22 \times 1 \mathrm{~mm}^{3}$ glass coverslips (pretreated with $0.3 \%$ gelatin) in 6 -well culture plates. After $24 \mathrm{~h}$ PPZ treatment, cells were fixed in ice-cold acetone for $10 \mathrm{~min}$ at $4{ }^{\circ} \mathrm{C}$. The cells were blocked with $10 \%$ normal goat serum (Boster Biotech, China) for $30 \mathrm{~min}$ and probed with HIF-1 $\alpha$ antibodies $(1: 100)$ at $4^{\circ} \mathrm{C}$ overnight. Alexa Fluor Dye Conjugated secondary antibodies (1:100, Alexa Fluor 488 goat anti-mouse IgG $(\mathrm{H}+\mathrm{L})$ highly cross-adsorbed, $2 \mathrm{mg} / \mathrm{ml}$, Invitrogen, USA) were used to incubate for $1 \mathrm{~h}$ to be visualized under a fluorescent microscope (Imager $\mathrm{A}_{1}$, Axio, Zeiss). Tumor tissues were cut into slices with a permanent cold icy slicker, fixed in ice-cold acetone in the same way, and then operated the same as the previous operation of cells. DAPI $(2 \mu \mathrm{g} / \mathrm{ml}$, Invitrogen, USA) was used to stain nuclei.

Cell proliferation assay. Cells were seeded $(10,000 /$ well $)$ into 96-well plates in $100 \mu \mathrm{l}$ medium per well and treated with PPZ for $24 \mathrm{~h}$. The antiproliferative effect of PPZ was assessed by Cell Counting Kit-8 (CCK-8) (KEYGEN Biotech, China) according to manufacturer's instruction, and expressed as relatively cell viability, using the following formula: Percent cell viability $(\%=\mathrm{OD}$ of drug-treated sample/OD of untreated sample) $\times 100 \%$. The experiment was repeated for three times.

Apoptosis analysis by flow cytometry. SGC-7901 cells were seeded into 6-well plates. After the PPZ administration according to the means mentioned above, the cells were trypsinised, washed twice with PBS, resuspended and then stained with an Annexin V-FITC Apoptosis Detection kit (KEYGEN Biotech, China). Apoptosis of cells was analyzed by a flow cytometer (BD Biosciences, USA). The experiment was repeated for three times.

Statistical analysis. Statistical analysis of the data was performed using the software package SPSS 13.0, the data were expressed as mean $\pm S D$ of the three independent experiments at least. The comparisons among different groups were evaluated by one-way ANOVA, using SNK, LSD and Dunnett's methods. Results were considered statistically different when the analysis returned a $P$ value of $<0.05$. 


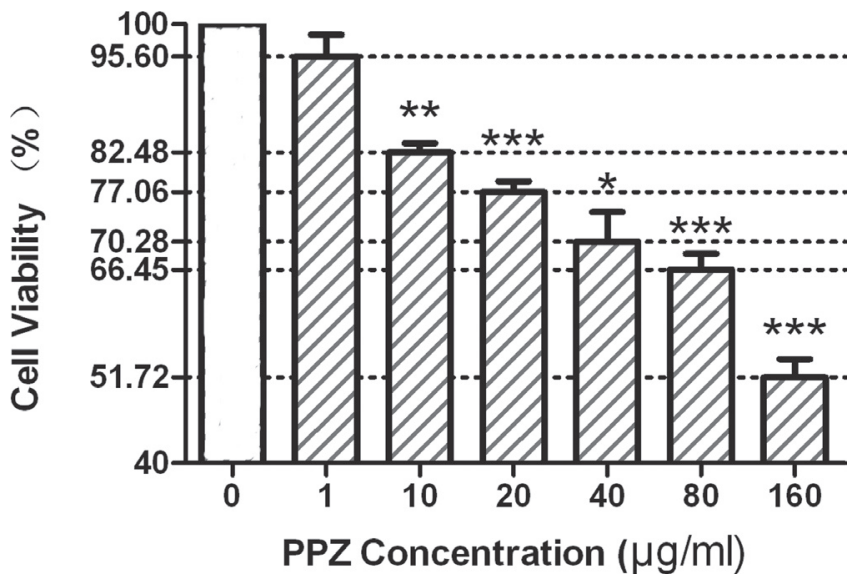

Figure 1. Comparison of the cell viability of SGC-7901 after the treatment of PPZ on different concentrations for $24 \mathrm{~h}$. Significance is shown compared with viability of SGC-7901 cells without PPZ (PPZ concentration is $0 \mu \mathrm{g} / \mathrm{ml})\left({ }^{*}, P<0.05 ;{ }^{* *}, P<0.01 ;{ }^{* * *}, P<0.001\right)$. The experiment was repeated for three times $(\mathrm{N}=3)$.

\section{Results}

PPZ suppresses SGC-7901 cell proliferation in a dosedependent manner. As shown in Fig. 1, PPZ could inhibit proliferation of the gastric cancer SGC-7901 cells in a dosedependent manner. The cell viability in 10, 20, 40, 80 and 160 $\mu \mathrm{g} / \mathrm{ml} \mathrm{PPZ} \mathrm{groups} \mathrm{was} \mathrm{significantly} \mathrm{lower} \mathrm{than} \mathrm{that} \mathrm{in} \mathrm{the}$ control group $(0 \mu \mathrm{g} / \mathrm{ml} \mathrm{PPZ})(-17.52 \%,-22.94 \%,-29.72 \%$, $-33.55 \%$ and $-48.28 \%$ respectively vs. the control group). Meanwhile, the cell viability in $1 \mu \mathrm{g} / \mathrm{ml} \mathrm{PPZ}$ group was also lower than the control group, whereas no significant difference was found between the two groups $(P>0.05)$.

PPZ induces apoptosis in SGC-7901 cells. A quantitative analysis of the fluorescent signals was performed by Fluorescence Activated Cell Sorting (FACS). The results are summarized in Fig. 2A and B. As displayed in Fig. 2B, PPZ could induce the early apoptosis and total apoptosis of SGC7901 cells dose-dependently, which is as follows: the early apoptosis rate in 1, 10, 20, 40, 80 and $160 \mu \mathrm{g} / \mathrm{ml} \mathrm{PPZ} \mathrm{groups}$ was markedly higher than that in the control group $(+1.64 \%$, $+8.17 \%,+12.00 \%,+18.97 \%,+49.10 \%$ and $+71.24 \%$ respectively vs. the control group, $P<0.001)$; the total apoptosis rate in $1,10,20,40,80$ and $160 \mu \mathrm{g} / \mathrm{ml} \mathrm{PPZ}$ groups was evidently higher than that in control group $(+7.53 \%,+21.76 \%,+24.10 \%$, $+44.73 \%,+56.20 \%$ and $+77.26 \%$ respectively vs. the control group, $P<0.001)$. PPZ could also induce late apoptosis of SGC7901 cells, but act not.dose-dependently, which was as below: the late apoptosis rate in 1, 10, 20, 40, 80 and $160 \mu \mathrm{g} / \mathrm{ml} \mathrm{PPZ}$ groups was evidently higher than that in the control group (+5.90\%, $+13.60 \%,+12.10 \%,+25.77 \%,+7.10 \%$ and $+6.04 \%$ respectively vs. the control group, $P<0.001)$.

PPZ inhibits protein expression of HIF-1 $\alpha$ in SGC-7901 cells. The expression of HIF-1 $\alpha$ in the SGC-7901 cells was ex- amined by western blot. The expressions of HIF-1 1 were much lower in PPZ treatment groups $(10-160 \mathrm{ug} / \mathrm{ml} ; 24 \mathrm{~h})$ than that in control group (Fig. 3). During different concentrations of PPZ treatment groups, $10 \mu \mathrm{g} / \mathrm{ml} \mathrm{PPZ} \mathrm{showed} \mathrm{the} \mathrm{most} \mathrm{powerful}$ inhibitory effects on HIF-1 1 expression.

PPZ influences the intracellular expression and distribution of HIF-1a. As an inhibitor of HIF-1a, PPZ treatment for $24 \mathrm{~h}$ on various concentrations caused a different intracellular expression and localization of HIF-1a vesicles (Fig. 4). After $10 \mu \mathrm{g} / \mathrm{ml} \mathrm{PPZ} \mathrm{treatment,} \mathrm{the} \mathrm{fluorescent} \mathrm{intensity}$ of HIF-1a expression significantly decreased compared to the control and other PPZ groups (Fig. 4B). After $20 \mu \mathrm{g} / \mathrm{ml}$ PPZ treatment, HIF-1 $\alpha$ was rather more dispersive than the control and other groups, instead of perinuclear accumulation phenomenon (Fig. 4C). Through PPZ administration with different concentrations, the fluorescent intensity of HIF-1a expression represented varying degrees of decline (some data not shown).

In a xenograft model of nude mice, administration of PPZ significantly inhibited tumorigenesis and down-regulated HIF-1 $\alpha$ protein. In a human gastric cancer xenograft model, we evaluated also the inhibition effects of PPZ in tumor growth and HIF-1a expression (Fig. 5). Intragastric administration of PPZ significantly inhibited tumorigenesis in mice of PPZ treatment group, with a drop in tumor volume at day 9 after the first PPZ administration compared with mice in control group $(P<0.05, \mathrm{n}=11$ for each group, Fig. 5A and $B)$, without severe side effects. The isolated tumors from mice with administration of PPZ were remarkably smaller than that of mice treated with normal saline (Fig. 5C). The expression of HIF-1 $\alpha$ in the PPZ treatment group was significantly lower than that in the control group (Fig. 5D and E).

\section{Discussion}

In a variety of human tumor cell lines or tissues, the role of HIF-1 $\alpha$ in cancer development has been described. However, whether HIF-1a is able to promote or inhibit tumor growth remains controversial. Between the two opponent points of view, one is that HIF-1 $\alpha$ is a positive factor in tumor growth, and its positive adjustment effect seems to be achieved by the expression of VEGF [16-18]; on the contrary, a slice of experiments elucidate that HIF-1a may inhibit tumor growth through its capacity of association with p53, which is a mediator of genotoxic apoptosis $[19,20]$. Our conclusions based on this study seem to be more supportive of the former, which is HIF-1a can promote tumor growth, in spite of absence of detecting VEGF. To get this judgment for the purpose of clarifying the issue, we made use of gastric adenocarcinoma cell line SGC-7901, intervened with the PPZ in vitro and in vivo respectively, observing the tumor cells proliferation and apoptosis, and simultaneously detecting the levels of HIF-1a expression.

This study showed that the expression of HIF-1a could be inhibited effectively under various concentrations of PPZ, 

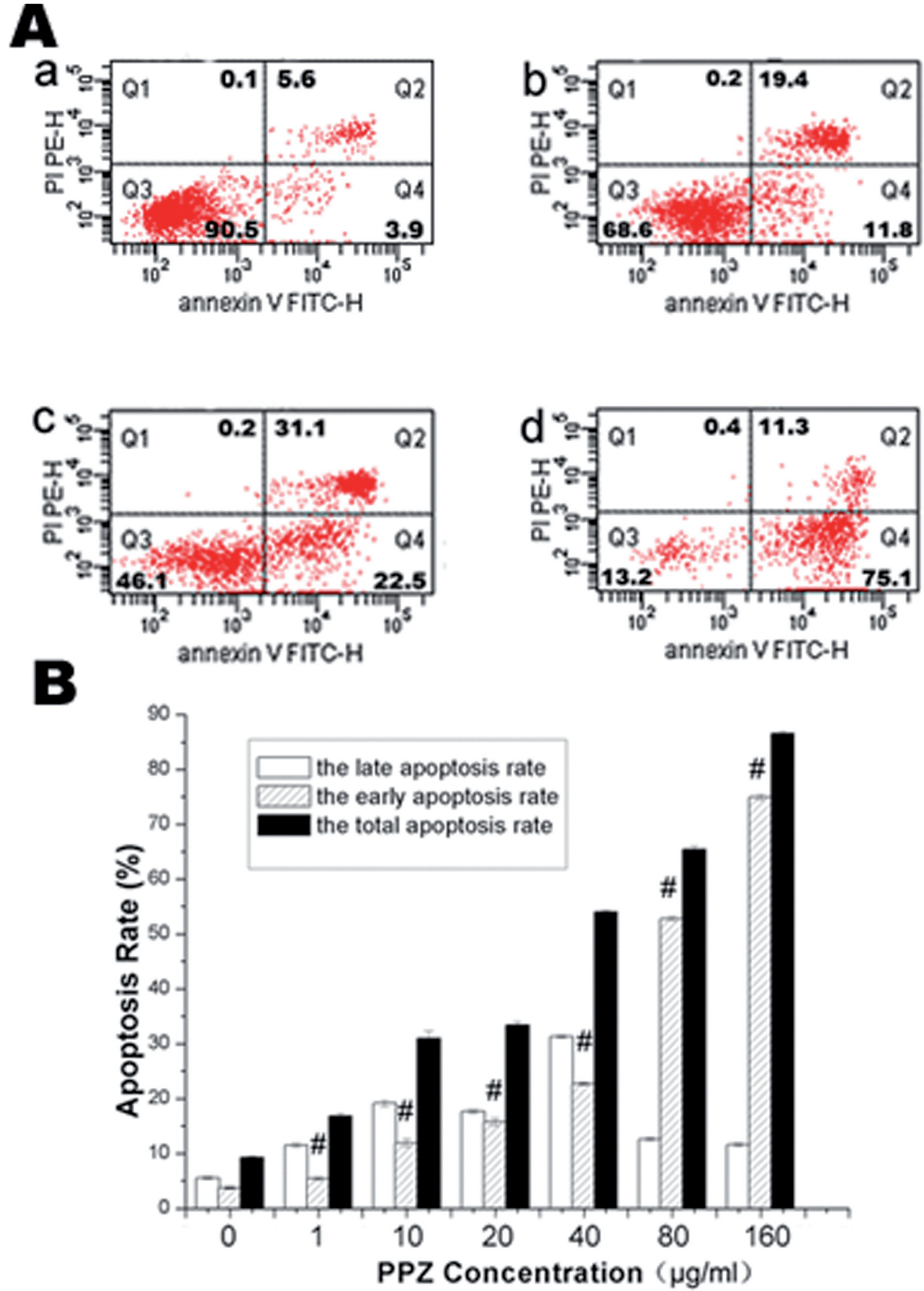

Figure 2. A) Comparison of the apoptosis rate of SGC-7901 cells after the administration of PPZ, a) the control group: PPZ concentration is $0 \mu \mathrm{g} / \mathrm{ml}, \mathrm{b}$ ) PPZ concentration is $10 \mu \mathrm{g} / \mathrm{ml}$, c) PPZ concentration is $40 \mu \mathrm{g} / \mathrm{ml}, \mathrm{d}$ ) PPZ concentration is $160 \mu \mathrm{g} / \mathrm{ml}$. B) Comparison of the apoptosis rate of SGC-7901 cells after the treatment of PPZ. \# $P<0.001$, the significance is shown compared with the control group (PPZ concentration is $0 \mu \mathrm{g} / \mathrm{ml})$. The experiment was repeated for three times $(\mathrm{N}=3)$.

but the interesting point is that acting on the most obvious inhibition effects is not the densest group, rather a relatively low concentration $(10 \mu \mathrm{g} / \mathrm{ml})$, which is not consistent with the effects of tumor cell proliferation and apoptosis. Contrary to a majority of reports [21-24], our study demonstrated that PPZ inhibited protein expression of HIF-1 $1 \alpha$ in an optimal dosage manner, or else a dramatic wording of "break point", instead of dose-dependent mode. This may be because the effects of 


\section{PPZ

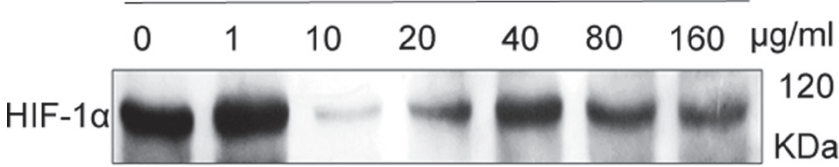

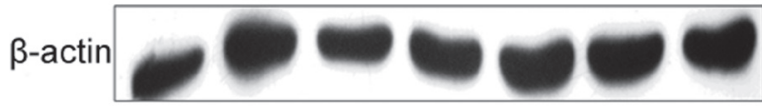

$\mathrm{KDa}$

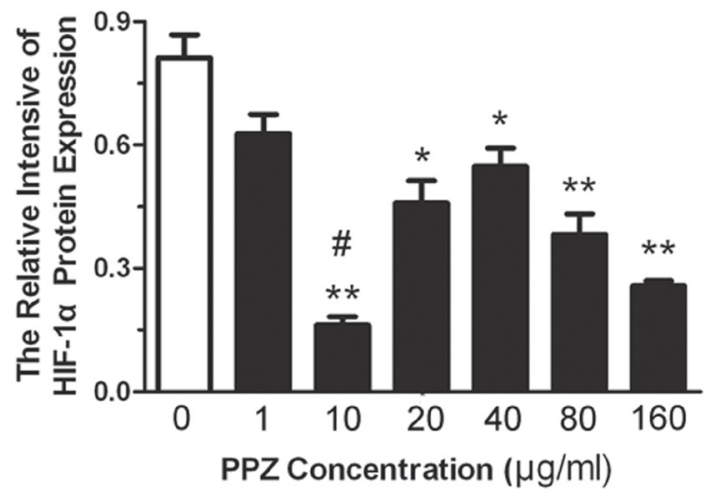

Figure 3. Effects of PPZ treatment on HIF-1a expression of SGC-7901 cells on different concentration points. ${ }^{*} P<0.05, * * P<0.01$, significant differences were revealed when compared to that in the $0 \mu \mathrm{g} / \mathrm{ml} \mathrm{PPZ} \mathrm{group.}$ $\# P<0.05$, there were significant differences between one group and other five groups among six PPZ treatment groups.
PPZ on tumor cells are not only through the changing levels of HIF- $1 \alpha$; as a matter of fact, the concrete mechanism is not yet clarified. One previous research has found that cancer cells were much more susceptible to growth inhibition of $\mathrm{PPZ}$ at a low $\mathrm{pH}$ [15], and the value of $\mathrm{pH}$ may also influence the protein expression related to tumor cells growth. However, all steps of our experiment were carried out at a neutral $\mathrm{pH}$, so the effects of PPZ at lower $\mathrm{pH}$ on the tumor cells growth need to be further studied. Immunofluorescence observations supported the results of Western Blot, in which the weakest fluorescent intensity was observed under the same concentration $(10 \mu \mathrm{g} / \mathrm{ml})$; however, when administered with $20 \mu \mathrm{g} / \mathrm{ml}$ PPZ, HIF-1 $a$ was dispersive without perinuclear accumulation phenomenon, indicating that pantoprazole had not only the inhibitory effect to HIF-1 $\alpha$, but also could affect its distribution in certain concentrations. As mentioned earlier [3], HIF-1a accumulated, entered into the nucleus and bound with HIF- $1 \beta$ to play a role, so its distribution could influence the activity indirectly.

The mechanisms of how PPZ affects the levels of HIF-1a remain unknown. Activation of HIF-1a involved a large number of intracellular signal transduction processes, such as mTOR [25, 26], EGFR [27], BCR/ABL [28] and Her2/neu [29] pathways, and the compounds acting on various signaling pathways mentioned above are likely to have the role of HIF-1 $\alpha$ inhibition. In post-translation phase, HIF-1 $1 \alpha$ also undergoes hydroxylation, acetylation, phosphorylation,
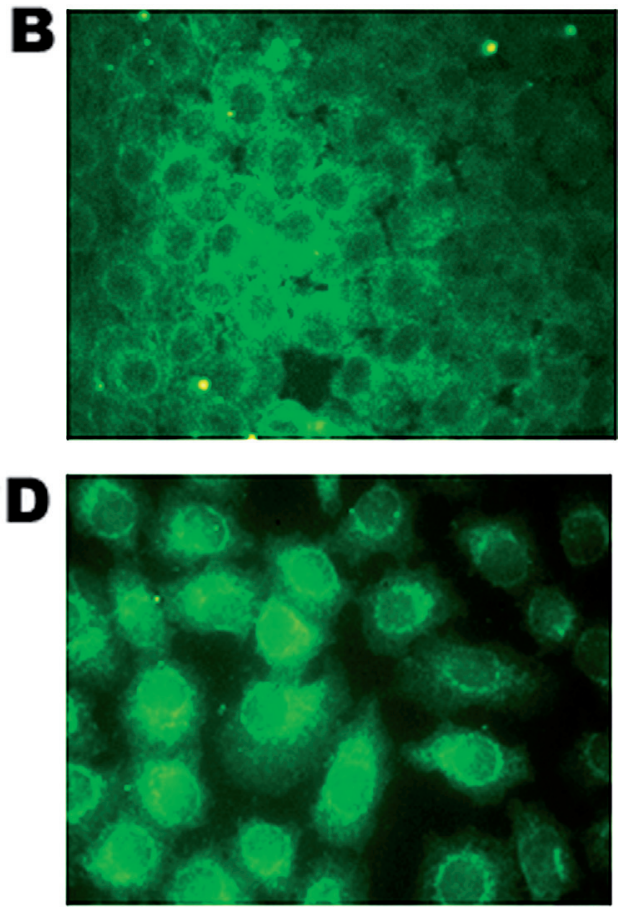

Fig. 4. Effects of PPZ treatment on the intracellular distributions of HIF-1 $\alpha$ in SGC-7901 cells. A) Intracellular distributions of HIF-1 $\alpha$ in SGC-7901 cells without PPZ treatment ( $\times 200$ magnification). B) Intracellular distributions of HIF-1 $\alpha$ in SGC-7901 cells after $10 \mu \mathrm{g} / \mathrm{ml} \mathrm{PPZ} \mathrm{treatment}(\times 200 \mathrm{magnifica}-$ tion). C) Intracellular distributions of HIF- $1 \alpha$ in SGC-7901 cells after $20 \mu \mathrm{g} / \mathrm{ml} \mathrm{PPZ} \mathrm{treatment}(\times 200$ magnification). D) Intracellular distributions of HIF- $1 \alpha$ in SGC-7901 cells after $160 \mu \mathrm{g} / \mathrm{ml}$ PPZ treatment (×200 magnification). 

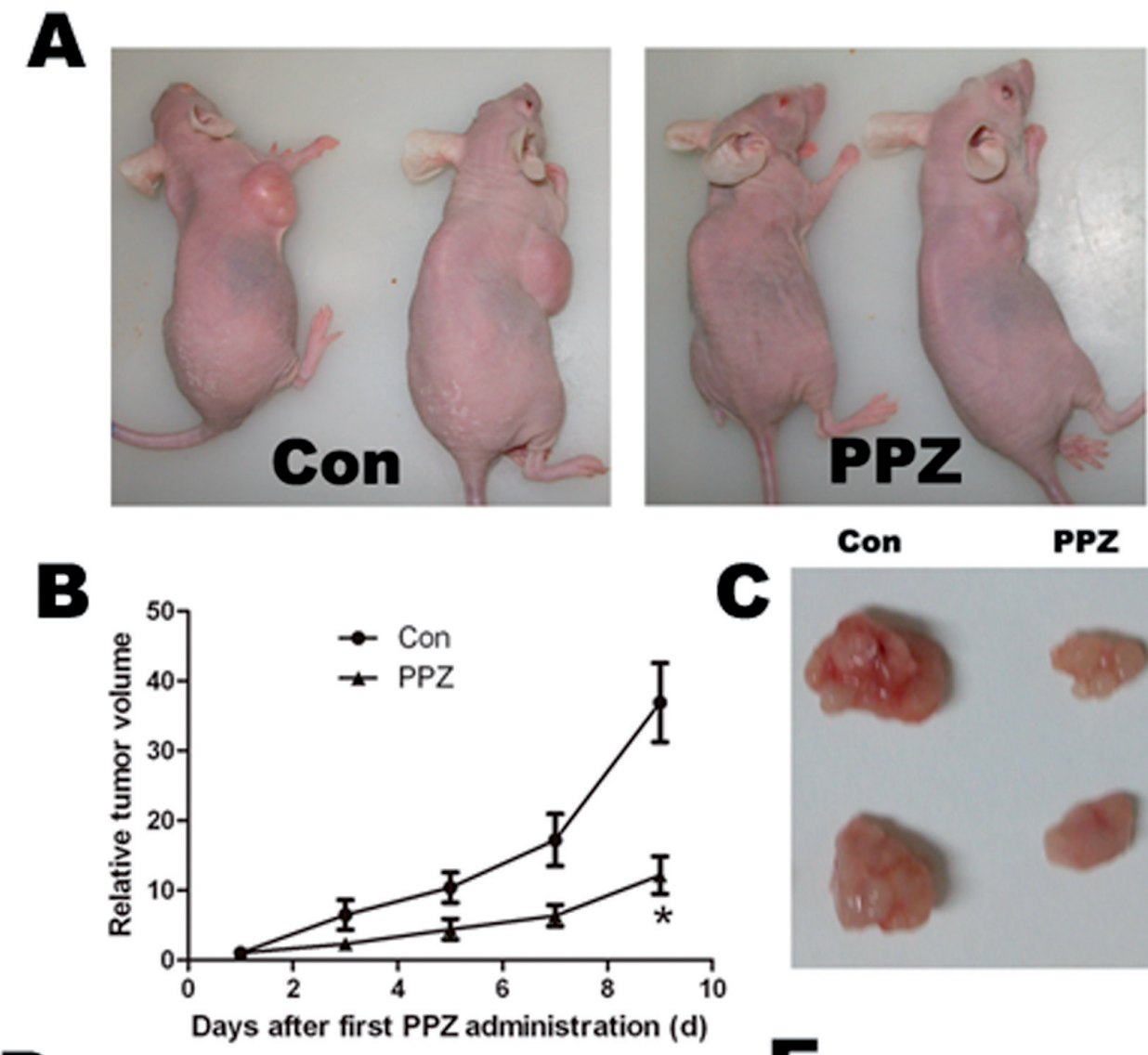

D)
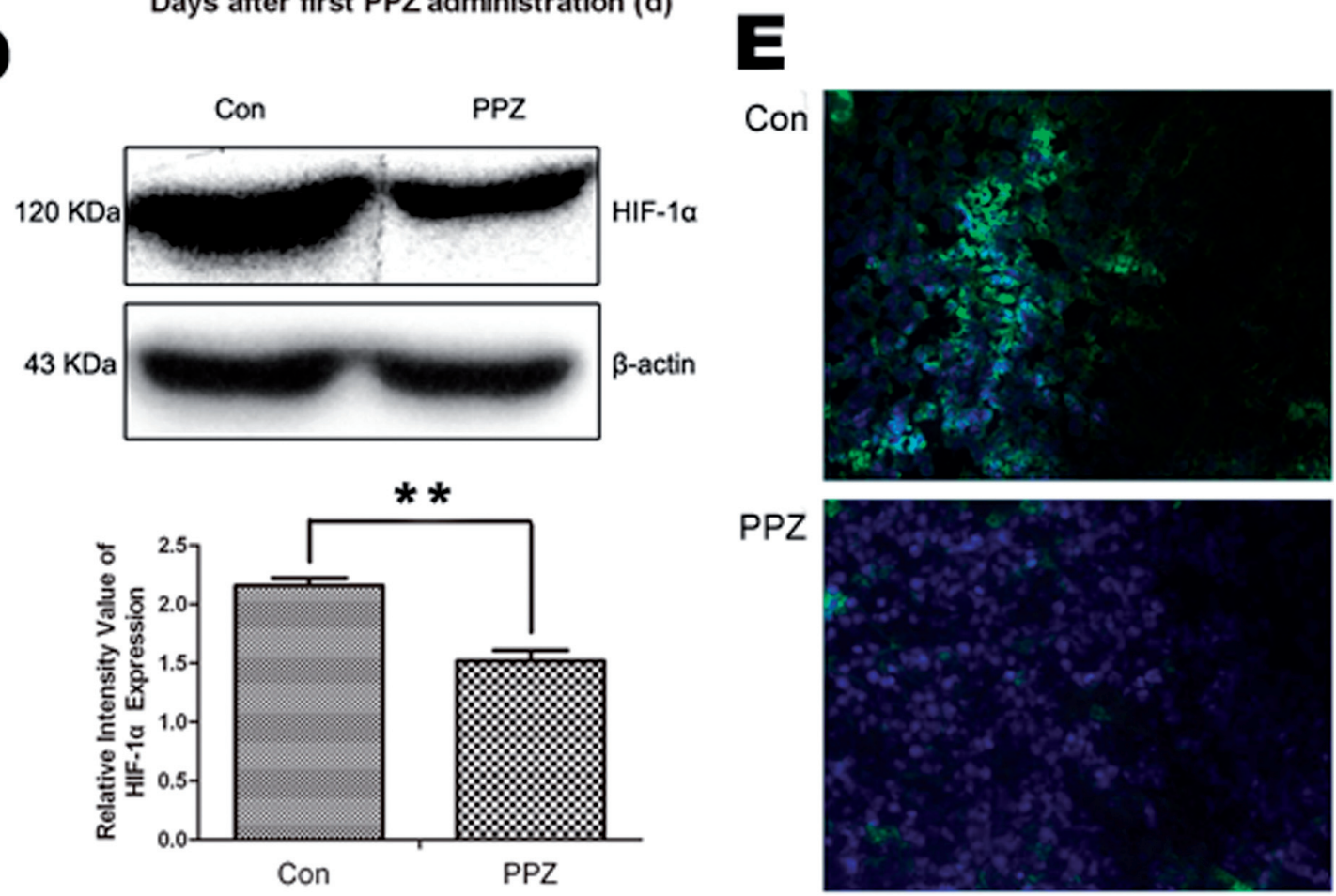

Fig. 5. Inhibition of tumorigenesis and HIF-1 $\alpha$ expression with PPZ in xenograft model. A) Comparison of the tumor volume after the treatment of PPZ for 9 days. B) Dynamic observation of the relative tumor volume after the first PPZ administration. C) Comparison of the isolated tumor volume after the sacrifices of nude mice. D) Effects of PPZ treatment on HIF-1 $\alpha$ expression of tumor samples. E) Effects of PPZ treatment on the levels of HIF-1 $\alpha$ protein in tumor tissues ( $\times 200$ magnification). Con: tumor-bearing mice treated with normal saline; PPZ: tumor-bearing mice treated with PPZ. $\left({ }^{*} P<0.05\right.$; $\left.{ }^{* *} P<0.01\right)$ 
ubiquitination and SUMO modification, and in recent years a large number of non-specific/specific inhibitors of HIF-1a have been discovered [30]. HIF is activated by hypoxia, but undergoes degradation by the VHL (von Hippel-Lindau) tumor suppressor protein in the presence of oxygen $[31,32]$. An increase in hydrogen ions elicits a transient and reversible loss of VHL function by promoting its nuclear sequestration [33]. Because of the abnormal cell metabolism, the hypoxic state in solid tumors often associated with tissue acidification, the extracellular $\mathrm{pH}$ value may reduce to below 6.0. The PPZ could inhibit tumor cell proton pump, change the acidification of tumor microenvironment [34] and increase VHL expression, which by the way so that increased the degradation of HIF-1a. On the other hand, benzimidazole analogue was found to regulate the stability of HIF-1a through the Hsp90Akt pathway, leading to the degradation of HIF-1 $\alpha$ [35], and we concluded that PPZ might inhibit HIF-1a expression as a kind of benzimidazole compounds. In a word, the inhibitory effects of PPZ on HIF-1a protein may involve several different factors.

Recent years witnessed considerable progress in numerous related experimental studies targeting HIF- $1 \alpha$, such as inhibiting HIF-1 $\alpha$ protein on gene level by RNA interference [36], suppressing the expression of HIF-1 1 by various drugs (mostly on post-transcriptional level, equaling the protein level) [35], and hydroxylating HIF-1 to induce the degradation of HIF-1 $\alpha$ under normoxia [37]. As a result, the research on anticancer therapy is getting more and more intensive. In summary, our findings pointed out the novel anticancer mechanism of gastric proton pump inhibitor, and extended the clinical application as an anticancer drug by inhibiting the expression of HIF-1a in cancer cells.

Acknowledgements: The study was supported by funding from National Science Foundation Grants (No. 81071816 and No. 81101814 ) and the fundamental research funds for the central universities (No. 021414340018). We also would like to thank Dr. Shanshan Shen for her linguistic assistance.

\section{References}

[1] WANG GL, JIANG BH, RUE EA, SEMENZA GL. Hypoxia-inducible factor 1 is a basic-helix-loop-helix-PAS heterodimer regulated by cellular $\mathrm{O} 2$ tension. Proc Natl Acad Sci USA 1995; 92: 5510-5514. http://dx.doi.org/10.1073/ pnas.92.12.5510

[2] WANG GL, SEMENZA GL. Purification and characterization of hypoxia-inducible factor 1. J Biol Chem 1995;270: 12301237. http://dx.doi.org/10.1074/jbc.270.3.1230

[3] MARÍN-HERNÁNDEZ A, GALLARDO-PÉREZ JC, RALPH SJ, RODRÍGUEZ-ENRÍQUEZ S, MORENO-SÁNCHEZ R. HIF-1 $a$ modulates energy metabolism in cancer cells by inducing over-expression of specific glycolytic isoforms. Mini Rev Med Chem 2009; 9: 1084-1101. http://dx.doi. org/10.2174/138955709788922610
[4] POON E, HARRIS AL, ASHCROFT M. Targeting the hypoxia-inducible factor (HIF) pathway in cancer. Expert Rev Mol Med 2009; 11: e26. http://dx.doi.org/10.1017/ $\underline{\mathrm{S} 1462399409001173}$

[5] VAUPEL P, MAYER A. Hypoxia in cancer: significance and impact on clinical outcome. Cancer Metastasis Rev 2007; 26: 225-239. http://dx.doi.org/10.1007/s10555-007-9055-1

[6] LIAO D, JOHNSON RS. Hypoxia: a key regulator of angiogenesis in cancer. Cancer Metastasis Rev 2007;26: 281-290. http://dx.doi.org/10.1007/s10555-007-9066-y

[7] MABJEESH NJ, ESCUIN D, LAVALLEE TM, PRIBLUDA VS, SWARTZ GM et al. 2ME2 inhibits tumor growth and angiogenesis by disrupting microtubules and dysregulating HIF. Cancer Cell 2003; 3: 363-375. http://dx.doi.org/10.1016/ S1535-6108(03)00077-1

[8] BOU KHEIR T, FUTOMA-KAZMIERCZAK E, JACOBSEN A, KROGH A, BARDRAM L et al. miR-449 inhibits cell proliferation and is down-regulated in gastric cancer. Mol Cancer 2011; 10: 29. http://dx.doi.org/10.1186/1476-4598-10-29

[9] MIZOKAMI K, KAKEJI Y, ODA S, IRIE K, YONEMURA T et al. Clinicopathologic significance of hypoxia-inducible factor 1alpha overexpression in gastric carcinomas. J Surg Oncol 2006; 94: 149-154. http://dx.doi.org/10.1002/jso.20568

[10] SUMIYOSHI Y, KAKEJI Y, EGASHIRA A, MIZOKAMI K, ORITA $\mathrm{H}$ et al. Overexpression of hypoxia-inducible factor lalpha and p53 is a marker for an unfavorable prognosis in gastric cancer. Clin Cancer Res 2006; 12: 5112-5117. http:// dx.doi.org/10.1158/1078-0432.CCR-05-2382

[11] URANO N, FUJIWARA Y, DOKI Y, TSUJIE M, YAMAMOTO $\mathrm{H}$ et al. Overexpression of hypoxia-inducible factor-1 alpha in gastric adenocarcinoma. Gastric Cancer 2006; 9: 44-49. http://dx.doi.org/10.1007/s10120-005-0356-1

[12] GRIFFITHS EA, PRITCHARD SA, VALENTINE HR, WHITCHELO N, BISHOP PW et al. Hypoxia-inducible factor-1alpha expression in the gastric carcinogenesis sequence and its prognostic role in gastric and gastro-oesophageal adenocarcinomas. Br J Cancer 2007; 96: 95-103. http://dx.doi. org/10.1038/sj.bjc.6603524

[13] YEO EJ, CHUN YS, CHO YS, KIM J, LEE JC et al. YC-1: a potential anticancer drug targeting hypoxia-inducible factor 1. J Natl Cancer Inst 2003;95: 516-525. http://dx.doi. org/10.1093/jnci/95.7.516

[14] STOELTZING O, MCCARTY MF, WEY JS, FAN F, LIU W et al. Role of hypoxia-inducible factor 1alpha in gastric cancer cell growth, angiogenesis, and vessel maturation. J Natl Cancer Inst 2004;96: 946-956. http://dx.doi.org/10.1093/ jnci/djh168

[15] YEO M, KIM DK, KIM YB, OH TY, LEE JE et al. Selective induction of apoptosis with proton pump inhibitor in gastric cancer cells. Clin Cancer Res 2004; 10: 8687-8696. http:// dx.doi.org/10.1158/1078-0432.CCR-04-1065

[16] RYAN HE, POLONI M, MCNULTY W, ELSON D, GASSMANN M et al. Hypoxia-inducible factor- $1 \alpha$ is a positive factor in solid tumor growth. Cancer Res 2000; 60: 40104015.

[17] FANG J, ZHOU Q, LIU LZ, XIA C, HU X et al. Apigenin inhibits tumor angiogenesis through decreasing HIF-1 $\alpha$ and 
VEGF expression. Carcinogenesis 2007; 28: 858-864. http:// dx.doi.org/10.1093/carcin/bgl205

[18] MIYAZAWA M, YASUDA M, FUJITA M, HIRABAYASHI K, HIRASAWA T et al. Granulosa cell tumor with activated mTOR-HIF-1 $\alpha$-VEGF pathway. J Obstet Gynaecol Res 2010; 36: 448-453. http://dx.doi.org/10.1111/j.14470756.2009.01127.x

[19] CARMELIET P, DOR Y, HERBERT JM, FUKUMURA D, BRUSSELMANS $\mathrm{K}$ et al. Role of HIF- $1 \alpha$ in hypoxia-mediated apoptosis, cell proliferation and tumour angiogenesis. Nature 1998; 394: 485-490. http://dx.doi.org/10.1038/28867

[20] AN WG, KANEKAL M, SIMON MC, MALTEPE E, BLAGOSKLONNY MV et al. Stabilization of wild-type p53 by hypoxia-inducible factor 1a. Nature 1998; 392: 405-408. http://dx.doi.org/10.1038/32925

[21] CHEN M, ZOU X, LUO H, CAO J, ZHANG X et al. Effects and mechanisms of proton pump inhibitors as a novel chemosensitizer on human gastric adenocarcinoma (SGC7901) cells. Cell Biol Int 2009; 33: 1008-1019. http://dx.doi.org/10.1016/ j.cellbi.2009.05.004

[22] BÖDVARSDÓTTIR TB, HOVE KD, GOTFREDSEN CF, PRIDAL L, VAAG A et al. Treatment with a proton pump inhibitor improves glycaemic control in Psammomys obesus, a model of type 2 diabetes. Diabetologia 2010; 53: 2220-2223. http://dx.doi.org/10.1007/s00125-010-1825-6

[23] TAKAGI T, NAITO Y, OKADA H, ISHII T, MIZUSHIMA $\mathrm{K}$ et al. Lansoprazole, a proton pump inhibitor, mediates anti-inflammatory effect in gastric mucosal cells through the induction of heme oxygenase-1 via activation of NF-E2-related factor 2 and oxidation of kelch-like ECH-associating protein 1. J Pharmacol Exp Ther 2009; 331: 255-264. http://dx.doi. org/10.1124/jpet.109.152702

[24] SCHILLINGER W, TEUCHER N, SOSSALLA S, KETTLEWELL S, WERNER C et al. Negative inotropy of the gastric proton pump inhibitor pantoprazole in myocardium from humans and rabbits: evaluation of mechanisms. Circulation 2007; 116: 57-66. http://dx.doi.org/10.1161/ CIRCULATIONAHA.106.666008

[25] MAJUMDER PK, FEBBO PG, BIKOFF R, BERGER R, XUE $\mathrm{Q}$ et al. mTOR inhibition reverses Akt-dependent prostate intraepithelial neoplasia through regulation of apoptotic and HIF-1-dependent pathways. Nat Med 2004; 10: 594-601. http://dx.doi.org/10.1038/nm1052

[26] WAN X, SHEN N, MENDOZA A, KHANNA C HELMAN LJ. CCI-779 inhibits rhabdomyosarcoma xenograft growth by an antiangiogenic mechanism linked to the targeting of mTOR/Hif-1 $\alpha$ /VEGF Signaling. Neoplasia 2006; 8: 394-401. http://dx.doi.org/10.1593/neo.05820

[27] PENG XH, KARNA P, CAO Z, JIANG BH, ZHOU M et al. Cross-talk between epidermal growth factor receptor and hypoxia-inducible factor-1 a signal pathways increases resistance to apoptosis by up-regulating survivin gene expression. J Biol Chem 2006; 281: 25903-25914. http://dx.doi.org/10.1074/jbc. $\underline{\mathrm{M} 603414200}$

[28] MAYERHOFER M, VALENT P, SPERR WR, GRIFFIN JD SILLABER C. BCR/ABL induces expression of vascular endothelial growth factor and its transcriptional activator, hypoxia inducible factor- $1 \alpha$, through a pathway involving phosphoinositide 3-kinase and the mammalian target of rapamycin. Blood 2002; 100: 3767-3775. http://dx.doi. org/10.1182/blood-2002-01-0109

[29] KOUKOURAKIS MI, SIMOPOULOS C, POLYCHRONIDIS A, PERENTE S, BOTAITIS S et al. The effect of trastuzumab/docatexel combination on breast cancer angiogenesis: dichotomus effect predictable by the HIF1 $\alpha$ /VEGF pre-treatment status? Anticancer Res 2003; 23: 1673-1680.

[30] HARRIS AL. Hypoxia-a key regulatory factor in tumour growth. Nat Rev Cancer 2002; 2: 38-47. http://dx.doi.org/ $\underline{10.1038 / \mathrm{nrc704}}$

[31] MAXWELL PH, WIESENER MS, CHANG GW, CLIFFORD SC, VAUX EC et al. The tumour suppressor protein VHL targets hypoxia-inducible factors for oxygen-dependent proteolysis. Nature 1999; 399: 271-275. http://dx.doi. org/10.1038/2045

[32] JAAKKOLA P, MOLE DR, TIAN YM, WILSON MI, GIELBERT $J$ et al. Targeting of HIF- $\alpha$ to the von Hippel-Lindau ubiquitylation complex by O2-regulated prolyl hydroxylation. Science 2001; 292: 468-472. http://dx.doi.org/10.1126/ science.1059796

[33] MEKHAIL K, GUNARATNAM L, BONICALZI ME LEE $\mathrm{S}$. HIF activation by $\mathrm{pH}$-dependent nucleolar sequestration of VHL. Nat. Cell Biol. 2004; 6: 642-647. http://dx.doi. org/10.1038/ncb1144

[34] LUCIANI F, SPADA M, MILITO AD, MOLINARI A, RIVOLTINI L et al. Effect of proton pump inhibitor pretreatment on resistance of solid tumors to cytotoxic drugs. J Natl Cancer Inst 2004; 96: 1702-1713. http://dx.doi.org/10.1093/jnci/ djh305

[35] WON MS, IM N, PARK S, BOOVANAHALLI SK, JIN Y et al. A novel benzimidazole analogue inhibits the hypoxiainducible factor (HIF)-1 pathway. Biochem Biophys Res Commun 2009; 385: 16-21. http://dx.doi.org/10.1016/ j.bbrc.2009.05.022

[36] HÄNZE J, EUL BG, SAVAI R, KRICK S, GOYAL P et al. RNA interference for HIF-1 $\alpha$ inhibits its downstream signalling and affects cellular proliferation. Biochem Biophys Res Commun 2003; 312: 571-577. http://dx.doi.org/10.1016/ j.bbrc.2003.10.153

[37] BRUEGGE K, JELKMANN W METZEN E. Hydroxylation of hypoxia-inducible transcription factors and chemical compounds targeting the HIF- $\alpha$ hydroxylases. Curr Med Chem 2007; 14: 1853-1862. 